\title{
TRADICIJSKO GRADITELJSTVO
}

\author{
Ivana ŠARIĆ ŽIC \\ Ministarstvo kulture \\ Uprava za zaštitu kulturne baštine \\ Konzervatorski odjel u Rijeci \\ Užarska 26, 51000 Rijeka
}

\section{UVOD 1}

$\mathrm{T}$ radicijsko graditeljstvo nastaje kao proizvod kolektivnoga znanja i vještina. Upravo zato to graditeljstvo ne promatram samo kao materijalnu vrijednost, već i kao dio duhovnoga i društvenoga, kulturnoga naslijeđa ovoga kraja, uvjetovano u prvome redu načinom života te klimatskim i zemljopisnim datostima. Graditelji su nam uglavnom nepoznati. Njihova djela na području Krivoga Puta odražavaju relativno veliku ujednačenost oblika i nesklonost naglim promjenama, pa se određeni (isti) tipovi i "stilovi" gradnje mogu pratiti kroz dulje vremensko razdoblje.

Temeljem terenskoga istraživanja provedenoga na području Krivoga Puta 2005. godine, obrađena su sljedeća sela i zaselci: Cigići, Cupići, Dudići-Brunići, Francikovac, Gornji Veljun, Klarićevac, Pavelići, Pavići, Rupa, Šojatski Dolac, Tomići, Vukelići, Zamalić i Žuljevići o čijoj tradicijskoj arhitekturi možemo doznati više u ovome poglavlju.

Prema zemljopisnim uvjetima, četrdesetak sela i zaselaka Krivoga Puta pripada području šumovitoga krasa (sl. 1), oštrih i dugih zima s mnogo snijega. Takav reljef ne omogućuje stvaranje većih ruralnih aglomeracija, pa su zaseoci rahle strukture i uglavnom broje tek po nekoliko pojedinačnih gospodarstava. Zaseoci su najčešće nazvani prema prezimenima pojedinih porodica (Pavići, Pavelići, Tomići i sl.). Ipak, u cjelini, iako zaseoci u vizuri djeluju kao da su razbacani bez nekoga unutarnjeg reda, pomnijom analizom uočava se promišljen smještaj svakog objekta obzirom na mjesne okolnosti (Muraj 1998:37). Izbor položaja

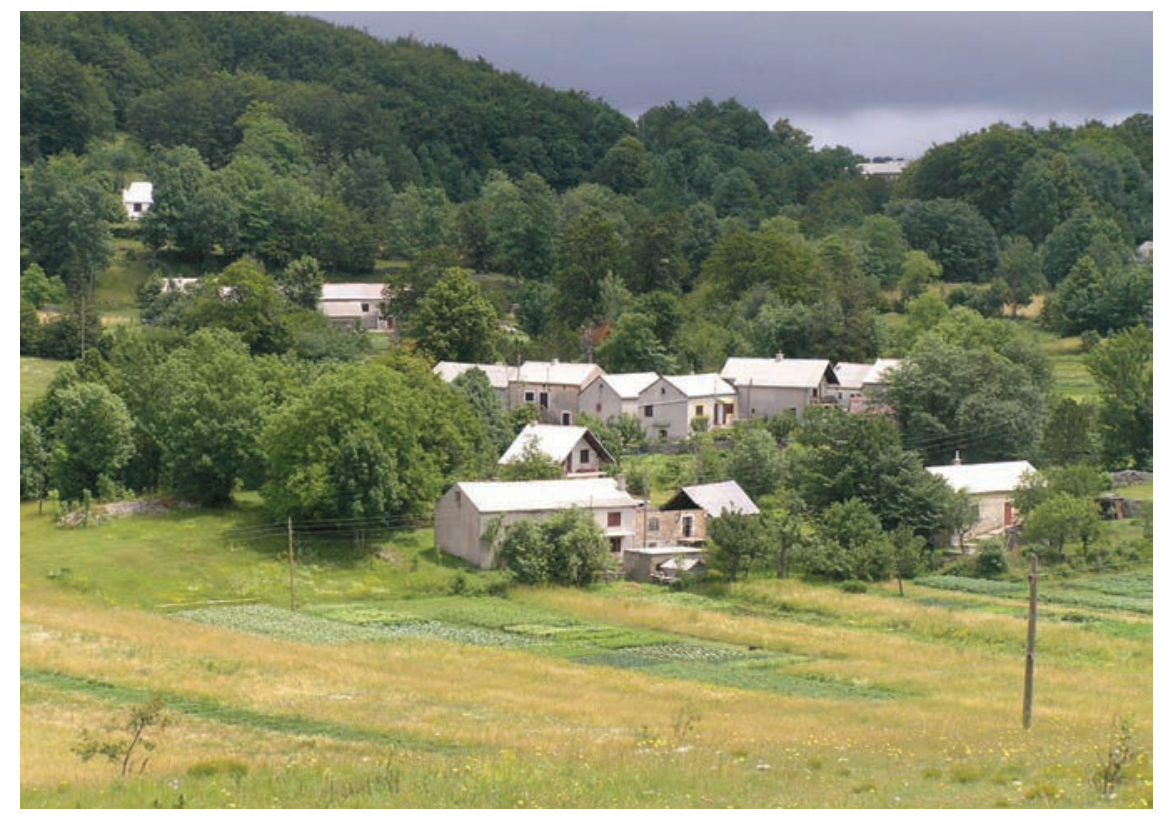

Slika 1: Donji Veljun u vizuri, lipanj 2005; snimila Marijeta Rajković.

Rad je, u sažetijem obliku, objavljen u Senjskom zborniku, 33, 2006. 
pojedinoga naselja nikada nije slučajan; on se vezuje uz put"eve, uz rubove obradivih površina, uz prisojne obronke te područja zaklonjena od bure.

\section{OBRAĐENOST TEME}

U tvrđivanjem zajedničkih karakteristika tradicijskog graditeljstva te uočavanjem eventualnih posebnosti u oblikovanju, namjerava se dati tipološka analiza tradicijske arhitekture Krivoga Puta i okolnih zaselaka. Krećući se od uopćenih opisa arhitektonsko-građevinskih značajki preko konkretnih primjera, opisane se pojave nastojalo barem okvirno datirati kako bi se mogli naslutiti razvojni procesi. Tradicijski elementi koji se pojavljuju nisu uvijek jednake geneze jer su ovisili o čitavom nizu ekonomskih, socijalnih i društvenih čimbenika. U konačnici, svaka je stambeno-gospodarska jedinica imala individualan razvoj u odnosu na potrebe svoga korisnika, stoga ova tema svakako zaslužuje daljnje ispitivanje.

Pregledom Arhive Konzervatorskog odjela u Rijeci² (fototeka, planoteka, lista Registra nepokretnih kulturnih dobara Republike Hrvatske) ustanovljeno je da za ovo područje ne postoji ranije izrađena dokumentacija te da na tom prostoru nema zaštićenih ruralnih cjelina. Stoga se nastojalo obići većinu sela odnosno zaselaka koji pripadaju području Krivoga Puta, kako bi se stekla što cjelovitija slika o zadanoj temi. Metodološki, rad se temelji na kombinaciji vlastitih opažanja te pojedinačnih razgovora s lokalnim stanovništvom.

U Arhivu Odsjeka za etnologiju i kulturnu antropologiju Filozofskog fakulteta u Zagrebu pohranjene su Upitnice Etnološkog atlasa (UEA), među kojima postoje i Upitnice tematski relevantne za proučavanje tradicijskoga graditeljstva: teme br.: 31-33, 35-36, 38-413. U okviru Upitnica obuhvaćena su pitanja o kućištu (okućnici) i kući za stanovanje ljudi, prostorijama i njihovoj namjeni, skladištu za žitarice, spremištu za vino, zidovima (stijenama) zgrada, krovu, otvorima na zgradama i visini prostorija, podovima, stropovima te unutrašnjoj obradi zidova. ${ }^{4}$ Pomoću navedenih Upitnica tema istraživala se, između ostalih, za lokalitet Krivi Put ${ }^{5}$, za koji sam pregledala podatke. U daljnjem tekstu navodit ću i komparirati podatke na koje, prilikom vlastitoga terenskog istraživanja tradicijskoga graditeljstva na području Krivoga Puta, nisam naišla ili koji se u nečemu međusobno razlikuju.

Tema tradicijskoga graditeljstva na području Krivoga Puta, kao i na znatno širem geografskom prostoru, izuzetno je slabo zastupljena u stručnoj literaturi. Prisutna je samo u uopćenim tipologijama gradnje na šumovitom krasu, bez uočavanja specifičnih pojava. Karakteristike te arhitekture nisu sustavno analizirane, tek su mjestimice iznošeni malobrojni podaci, uglavnom u kontekstu istraživanja drugih tema. Stoga je neophodno nastaviti sa sustavnom analizom pojedinih okućnica i unutar širega geografskog prostora Velebita kako bi se uočile potencijalne posebnosti opisanoga područja Krivoga Puta.

U radu iz 2000. godine Milana Černelić, usredotočena na istraživanje zadružnih obitelji, donosi i vrlo opsežan zapis o izgledu kuće i okućnice. U radu se detaljno izlaže unutarnja dispozicija prostora, lokalni nazivi mobilijara, te autorica navodi pojedine graditeljske elemente i termine koje, istražujući dvadeset i sedam godina poslije, osobno nisam na terenu zabilježila. ${ }^{6}$

2 Odjel Ministarstva kulture Republike Hrvatske, Uprava za zaštitu kulturne baštine.

3 Upitnice Etnološkog atlasa (UEA) pohranjene su u Arhivu Odsjeka za etnologiju i kulturnu antropologiju Filozofskog fakulteta u Zagrebu.

4 Dobiveni podaci iz navedene Upitnice uglavnom se poklapaju s onima dobivenim tijekom istraživanja provedenih na Krivome Putu 2004. i 2005. godine, no podaci iz Upitnice vrlo su nedostatni i šturi, često tek u vidu potvrdnog ili negativnog odgovora te mogu poslužiti tek kao polazište za detaljnija istraživanja. Prilikom terenskoga istraživanja na Krivome Putu 2004. i 2005. godine ispitivanje je vršeno prema proširenoj upitnici, prethodno pripremljenoj za krivoputsko područje, no, prilikom sastavljanja šire upitnice, polazilo se od navedene UEA.

5 Upitnice za teme iz tradicijskog graditeljstva, za lokalitet Krivi Put, nalaze se u Arhivu pod signaturom: UEA, Fd $241 / 1382$.

6 U opisu kuće i kućišta zadruge Prpić-Grgajice u Kosovoj Buljimi autorica govori o kući katnici, građenoj od kamena, pokrivenoj šimlom, što se i uklapa u uočenu tipologiju. Donosi i termin balatura (svojstven području uz more) kojim opisuje ulazni trijem u kuću. U gornjem dijelu kuće u sredini se nalazila kuhinja i dvije sobe sa svake strane. (...) Cijelom dužinom sobe prema cesti prostirala se supa, otvorena, na četiri stupa, natkrita krovom od šimle. To je bilo spremište za kola 
Izrazito romantičarski rad Rikarda Pavelića Bunjevci, pisan 1973. godine, sporadično donosi podatke o tradicijskoj arhitekturi. ${ }^{7}$ Čini se kako je autor primarno imao na umu opisati krmpotski kraj, također naseljen primorskim Bunjevcima, obzirom da ističe kupu kao krovni pokrov koji na krivoputskome prostoru nije zastupljen. Općenito, autor generalizira sve (primorske) Bunjevce, ne navodeći specifičnosti pojedinoga područja, a time ni sela i zaselaka pa tako ne spominje zasebno ni Krivi Put.

U poznatom pregledu tradicijske arhitekture Kako narod gradi, u kojem se ne bavi primorskim Bunjevcima, ali opisuje karakteristike gradnje uvjetovane terenom, Freudenreich navodi: Karakteristična zajednička crta stambenih objekata šumovitog Krasa je u tom da se staja gradi redovito pod istim krovom a ne u posebnoj zgradi. Na prizemnicama je na jednu stranu stan dok je na drugoj strani staja. U katnicama odnosno zgradama s podrumom gradi se stan u gornjem katu dok su staje u podrumskim katovima. (Freudenreich 1972:98) Doprinos temi daje i rad autorice Marijete Rajković koja se bavi problematikom sezonskih migracija na području Krivoga Puta. U okviru teme seljenja na ljetne stanove dan je i prilog razlikovanju arhitekture i kulture stanovanja domicilnoga i selilačkoga stanovništva, koji su nerijetko obitavali u istome zaselku.

Obilježja tradicijskoga graditeljstva šire regije, odnosno područja južno od Krivoga Puta (prostor Nacionalnog parka Sjeverni Velebit, ruralna cjelina Turinski Krč), predmet su i sustavnih istraživanja Helene Knifić Schaps. Radovi su objavljeni u Senjskim zbornicima, a u njima nalazimo brojne podatke koji predstavljaju važan doprinos komparativnoj analizi odlika tradicijskoga graditeljstva krivoputskoga i okolnoga područja.

\section{TRADICIJSKO GRADITELJSTVO KAO PRILOG POZNAVANJU BUNJEVAČKOGA IDENTITETA I ETNOGENEZE}

$\mathrm{P}$ odručje Krivoga Puta odlikuje kvalitetno, nerijetko intaktno, očuvano tradicijsko graditeljstvo. (sl. 2) Takvome dojmu svakako doprinose i skladno očuvane prirodne vizure. U tim cjelinama, koje nisu izložene suvremenim neprimjerenim graditeljskim zahvatima, gdje nema trenda neprikladnih dogradnji, nadogradnji i upotrebe neadekvatnih materijala, uviđamo drugu krajnost - potpuno propadanje arhitekture.

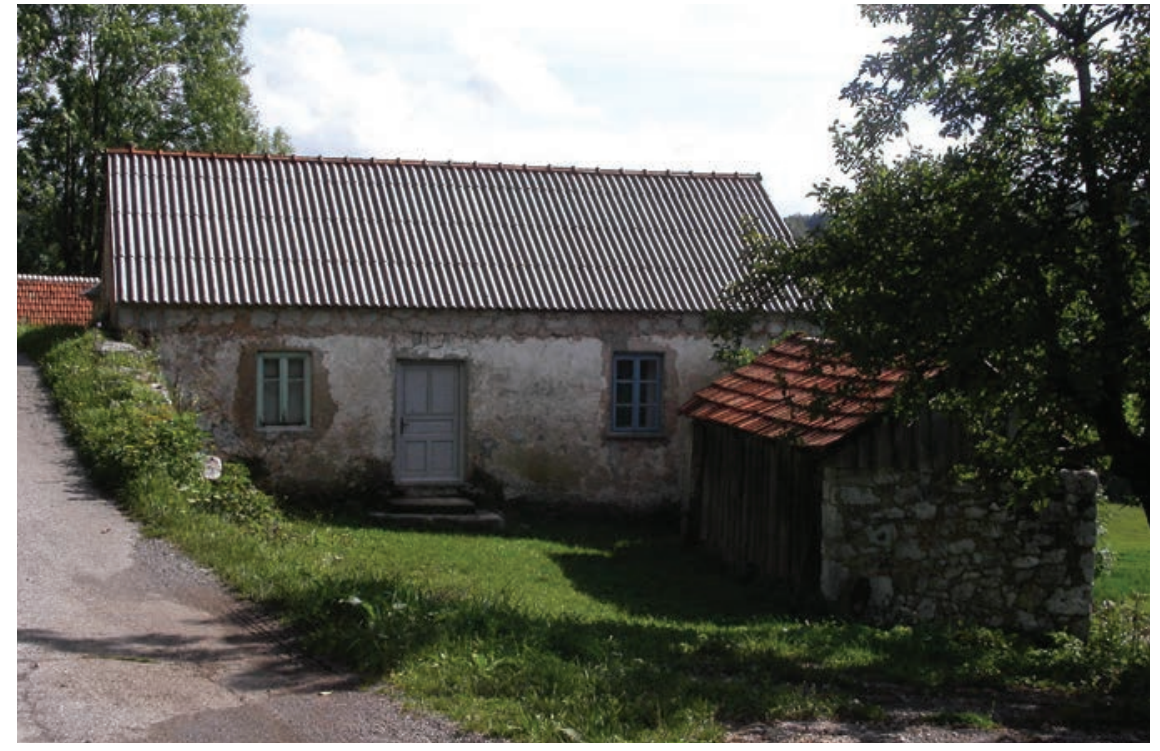

Slike 2: Gornji Veljun, rujan 2005; snimila Ivana Šaric Žic.

i poljske alate. Ispod svake sobe bila je štala, a ispod kubinje konoba. (Černelić 2000:203-205) Termin koji recentnim obilaskom nije zabilježen, a prisutan je u radu autorice, jest i klitar, prostor za čuvanje krumpira u konobi.

Da bi odoljeli tako dugačkoj i oštroj zimi, koja zna potrajati od listopada do travnja mjeseca iduće godine, Bunjevci ovog podneblja sagradiše kamene kuće pokrivene jelovom šindrom, a rijede kupom, tako da je u podrumu (konobi) mjesta za stoku, iznad stoke je čeljad, a na „podu“ (tavanu) sijeno. Ponekad se i trapovi za krumpir kopaju u konobi (podrumu) kuće. (Pavelić 1973:176) 
Godinama izloženo procesu sustavne depopulacije, to područje danas predstavlja kvalitetan poligon na kojemu je moguć planski pristup sa svrhom sprečavanja nekontrolirane nove gradnje. Izvođenje takve „ne-arhitekture“ za posljedicu bi imalo i devastaciju okolnoga kultiviranog krajolika. Obilazeći teren, ponekad je na prvi pogled teško ustanoviti radi li se o adaptiranim starijim objektima ili je riječ o novoj gradnji, obzirom da ona gabaritima i oblikovanjem pročelja (pojavljuju se tek manji balkoni) bitno ne odskače od naslijeđene tipologije. Na mnogim je građevinama vidljiva minimalna, ali konstantna briga jer je velik broj pripadnika bunjevačke zajednice emigrirao u Senj.

Po stanju očuvanosti tradicijskoga graditeljstva, od ostalog se prostora izdvaja Bunica, smještena na samoj morskoj obali te samim tim izloženija arhitektonskim preinakama u skladu s potrebama turističke ponude.

Odmaknemo li se od analize pojedinih arhitektonskih elemenata tradicijske gradnje te promotrimo li arhitekturu u cjelini, uvidjet ćemo kako je stambeni prostor kojega je koristio primorski Bunjevac površinom gotovo istovjetan prostoru koji je bio namijenjen stoci. Takav izjednačen odnos stambenoga i gospodarskoga dijela jasno upućuje na značaj koji je čovjek pridavao blagu. Stočarstvo je kao jedna od najvažnijih gospodarskih grana ${ }^{8}$ bilo i važan izvor prehrane i prihoda lokalnog stanovništva. Takva ravnomjerna razdioba životnoga prostora to nepobitno potvrđuje.

Arhitektura koju danas zatičemo na području Krivoga Puta različite je datacije i tipologije. Međutim, slijedeći njezin dijakronijski razvoj, kao konstantu uočavamo važnost koja se pridaje prostoru za stoku što je značajno uvjetovalo izgled i funkcionalnost arhitekture. Izgled tradicijskoga graditeljstva sinteza je relativno surovih prirodnih okolnosti koje definiraju taj zemljopisni predio, kao i potrebe Bunjevaca koji, prema poznatim podacima, na te prostore doseljavaju kao stočari, što znatno utječe na način života njihove zajednice.

Po provedenim će se istraživanjima karakteristika tradicijskoga graditeljstva svih bunjevačkih ogranaka komparativnom analizom moći utvrditi sličnosti i razlike, te koliko su različiti uvjeti života, različito povijesno, društveno, kulturno i etničko okruženje snažno utjecali na konstrukciju identiteta (Černelić 2005:31). $\mathrm{U}$ ovoj fazi istraživanja, bez potpunoga poznavanja arhitekture ostalih grana Bunjevaca, kao i arhitekture prostora s kojega potječu, konačni odgovor na pitanje koji su to arhitektonski elementi zajednički svim granama Bunjevaca nije moguće dati. Ono što je nesumnjiv odraz bunjevačkoga identiteta svakako jest funkcija same arhitekture, koja je u prvome redu podređena stočarstvu.

Bavljenje stokom jedna je od glavnih odrednica po kojima su bunjevačko stanovništvo prepoznavali pripadnici susjednih zajednica, u prvom redu građani Senja. Takva predodžba zadržala se među Senjanima i nakon što su se žitelji sela podno Senjskog bila usmjerili na druge vidove privredivanja. (...) Tako Grgo Nekić iz Žuklja obrazlažé:,Senjani nami i danas reču pastiri, ovčari, neka vǐ̌e nema skoro nijedne ovce po ovim selima.“. (Škrbić Alempijević 2003:435-436) S punim se pravom može ustvrditi da u sintagmi „primorski Bunjevi“" atribut „primorski“ označuje samo njihov smještaj u odnosu na rasprostranjenost drugih bunjevačkih grana, a ne i stvarnu vezu koju su uspostavili smorem (...), najmanje upravo u oblicima tradicijskog gospodarstva (Škrbić Alempijević 2003:439).

Problematika tipa stočarenja kojim su se Bunjevci na ovom prostoru bavili bitno je složenija i nije predmet ovoga rada. Obzirom na njihovo dinarsko podrijetlo očekivalo bi se da će u njih prevladavati transhumantni tip stočarstva, ${ }^{9}$ međutim recentnija istraživanja ${ }^{10}$ promišljaju primorske Bunjevce i kao

8 Detaljnije o tradicijskom gospodarstvu u radu M. Rajković (prilog u Monografiji).

9 Osnovna značajka transhumantnog stočarstva jest da su vlasnici stada (u pravilu je riječ o ovcama) nastanjeni u stalnim naseljima gdje se bave skromnom zemljoradnjom, dok su sama stada i ljeti i zimi na pašnjacima gdje ih čuvaju pastiri. Ovo potonje bilo je uvjetovano ćinjenicom da pojedini vlasnici stada sve donedavno nisu prikupljali krmu (sijeno) za zimu, pa je stoka morala zimi tražiti pašu u toplijim... krajevima uz more. (Belaj 2004:9)

10 Vidi detaljnije u: Belaj 2004:5-31. 
nositelje alpskog tipa stočarenja. ${ }^{11}$ Veza etnogeneze i (alpskog) tipa stočarenja ukazivala bi na mogućnost otkrivanja kulturnopovijesnih procesa u kojima je neko staro, po podrijetlu predindoevropsko stanovništvo sa svojim specifičnim načinom života sudjelovalo u nastajanju etničke skupine poznate pod imenom Bunjevci (Belaj 2004:5).

Sustavni obilazak terena radi ubiciranja mogućih lokacija na koje se selilo te temeljitija istraživanja ostataka arhitekture na višim nadmorskim visinama mogla bi metodološki pomoći u definiranju tipa stočarenja primorskih Bunjevaca. Stoga bi izneseni podaci trebali dati doprinos i novim spoznajama o identitetu i etnogenezi Bunjevaca. ${ }^{12}$

\subsection{ANALIZA GRADITELJSTVA}

Tradicijsko graditeljstvo Krivoga Puta i njegove okolice, bilo stambene ili gospodarske namjene, odlikuju izrazito pojednostavljeni oblici. (sl. 3)

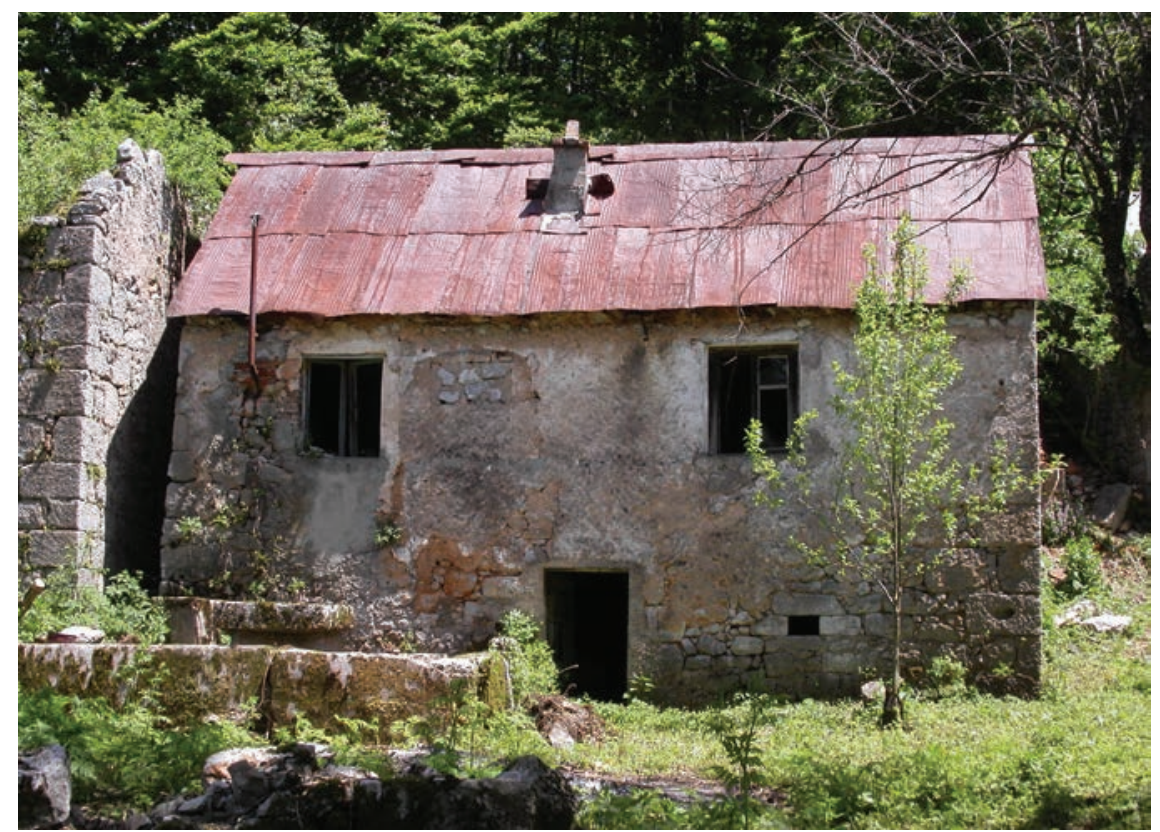

Slika 3: Cigicí, svibanj 2005; snimila Ivana Šarić Žic.

Riječ je o ekonomičnoj i funkcionalnoj gradnji, vrlo „čistih“ pročelja, bez dekorativnih elemenata. Može se reći kako je ovdašnja arhitektura, ostvarena na kompoziciji jednostavnih formi, uistinu odraz čovjekovih osnovnih egzistencijalnih potreba i mogućnosti.

11 Bitne značajke alpskog stočarstva su da je zimi cijela obitelj, zajedno sa stokom u matičnom selu i stoku krme sijenom. U proljeće odvija se izdig cijelog sela zajedno sa stokom. Ondje obraduju vrtove (motičarstvo) i nerijetko njive, te prikupljaju sijeno za zimu. Visoko ljeto (srpanj, kolovoz), dok obitelj živi i radi u ljetnom stanu, pastiri odlaze sa stokom na planinu, tj. na visoke pašnjake, gdje imaju stanove i kolibe za spravljanje sira. (...) U jesen pastiri se sa stokom vraćaju na majska selišta. Nakon toga svi se spremaju za silazak u donje, zimsko selo, noseći sa sobom plodine i sijeno za krmu. (Rajković 2005: 311)

12 Prema pojedinim autorima, iz termina bunja (oblik stočarske nastambe), izvodi se etnonim Bunjevac. Iako namjera rada nije analiza raširenosti toga oblika nastambi, dostupna literatura bilježi postojanje bunja i na ovom području. Nastambe slične bunjama u Dalmatinskoj zagori gradili su sve do prije tridesetak godina i Bunjevci u Velebitskom primorju (Podgorci) kao i Bunjevci u senjskom i novljanskom zaledu. To su bile ljetne nastambe (stanovi, stanine) koje su žitelji iz Primorja gradili na Velebitu i Senjskoj planini. U tim su stanovima živjeli Bunjevci za vrijeme sezonskih radova (košnja trave, sadnja i kopanje krumpira). I ove nastambe Bunjevaca iz Hrvatskoga primorja gradene su od kamena u suhom zidu, ali više nisu bile pokrivane kamenim pločama nego jelovom šindrom (šimla), jer Velebit i Zapadna Kapela obiluju jelom $i$ smrekom. Na tlu Krmpota i Krivog puta i danas nalazimo ostatke prvih bunjevačkih naseobina gradenih od kamena $i$ bez vezivnoag materijala. To su prije svega stanovi na današnjem Stanića Brigu u Krivome putu... (Pavelić 1973:18-19) 
Ovom etnološkom analizom izostavljeni su podaci koji se odnose na konstruktivne elemente (detalji krovišta i međukatne konstrukcije, precizni omjeri građevnoga materijala, problematika temeljenja). Detaljan opis etnografskog mobilijara koji se nalazio u kućama također nije predmet ovog rada, te se ne donose podaci o njegovim nazivima i funkcijama.

Prema viđenomu, razlikujemo dva osnovna tipa gradnje koja se temelje na principu korištenja prostora:

- prostor namijenjen zajedničkom obitavanju ljudi i stoke; „pod istim krovom“,

- $\quad$ prostor namijenjen zasebnom obitavanju ljudi i zasebnom obitavanju stoke. ${ }^{13}$

Uvidom u tradicijsko graditeljstvo ovog područja, možemo potvrditi ranije istaknutu Freudenreichovu tezu o suživotu stoke i čovjeka pod istim krovom, no i ukazati na postojanje tipa arhitekture koji dijeli životni prostor čovjeka od onoga namijenjenoga stoci (sl. 4). Suživot ljudi i blaga pod istim krovom zasigurno je stariji tip ruralnoga stanovanja. Može se pretpostaviti kako se najprije pojavljuje uvjetno nazvana horizontalna podjela: ljudi i stoka žive u istoj prizemnoj etaži, a dijeli ih tek pregradni zid. Pojavom gornje etaže ta se podjela odvija po vertikali: stoka je boravila u donjoj etaži, a ljudi u gornjoj. Štale se kao zasebne građevine javljaju krajem 19. i početkom 20. stoljeća, što se pretpostavlja temeljem uklesanih datacija na pripadajućim stambenim jedinicama.

Kao posebna tema nameće se i problematika razlikovanja građevina koje su služile stalno naseljenom stanovništvu od onih koje je puk gradio za povremeno boravište prilikom seljenja na ljetne stanove. Pojedina su naselja imala karakter povremenoga i stalnoga boravišta pa tako neka od njih iz ljetnih stanova prerastaju u stalno naseljena područja. Danas je podatke o povijesnom razvoju pojedinih zaselaka nemoguće utvrditi bez sustavnih arhivskih istraživanja, upravo stoga što slična/identična obilježja stalne/selilačke arhitekture ne mogu poslužiti kao siguran putokaz.

Iako se nisam iscrpnije bavila tom temom, iz rada već spomenute autorice M. Rajković proizlazi da i u izgledu arhitekture selilačkog stanovništva nije moguće utvrditi konstantu, već on ovisi o mogućnostima i potrebama pojedinaca. Obzirom da selilačko stanovništvo nije u tim naseljima boravilo u najsurovijim zimskim mjesecima, njihove su potrebe za životnim prostorom bile skromnije. Sudeći prema prikupljenim podacima autorice, tlocrti povremeno nastanjenih građevina, kao i u slučaju stambene arhitekture, ovisili su o mogućnostima pojedine obitelji: Kako je $k o$ mogao. ${ }^{14} \mathrm{U}$ prosjeku se ipak radilo o lošijim građevinskim primjerima u odnosu na stalno naseljene građevine: Kúce od ljudi koji su stalno gore boravili su črršce gradene zbog zime. Mora bit da ne puše i da ne kaplje, i štalice su morale biti jer tamo zapada tri metra snijega, a ove za litnja doba nema veze. Nisu ni imali od čega napravit. Oni se nisu privikavali na zimu. Oni su dolje imali bolje kuće nego ovi gore. ${ }^{15}$ Kao i u slučaju stambene arhitekture, zabilježena su dva tipa gradnje prema principu korištenja prostora: zasebne građevine za čovjeka i stoku te građevine za njihov zajednički boravak (ista etaža/različite etaže).${ }^{16}$

13 Unašim je krajevima, inače, tek relativno blagostanje bilo odlučujuće da seljak napusti tu ipak nehigijensku organizaciju i stoku premjesti u štalu kao posebnu zgradu. (Živković 1993:48)

14 Milan Tomljanović Periša (prema: Rajković 2005:287).

15 Tome Špalj Cucin i Petar Tomljanović Jukša (prema: Ibid.).

16 Autorica donosi termin pojate za najjednostavniju jednoprostornu građevinu ljetnog stana. 


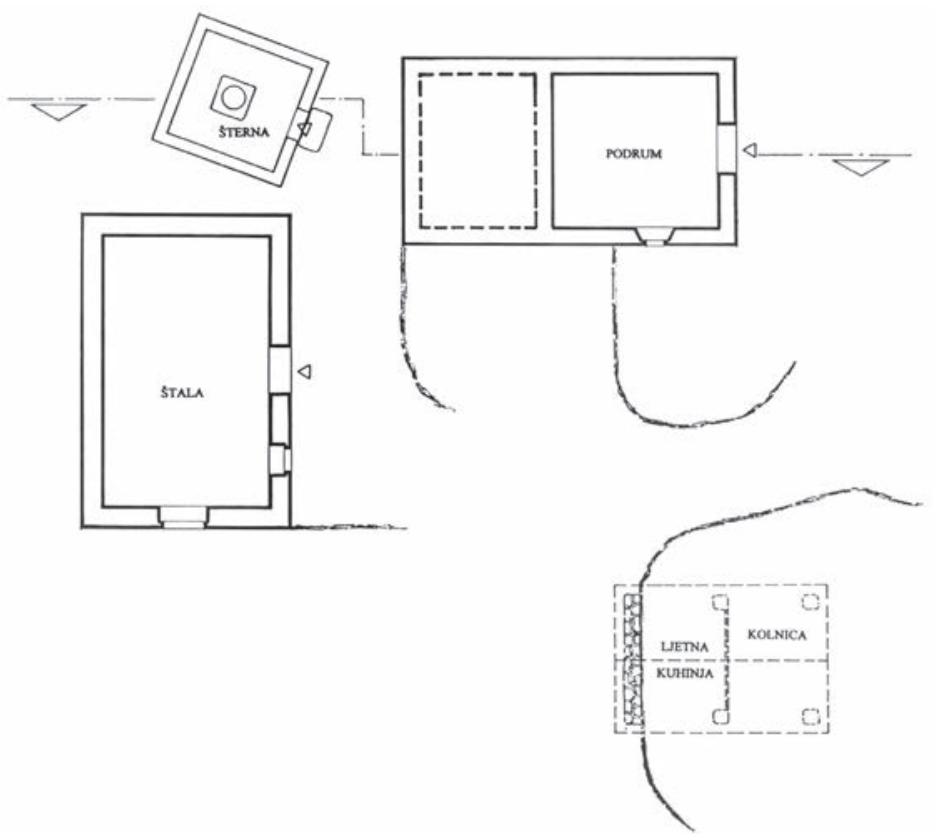

MINISTARSTVO KULTURE Konzervatorsti odjel 1 i Rijeci

Mjesto : sjeverni Velebit, Pavidi Namjena : stambeno- gospodar Snimila: Ana Presten. Rijeka, sppanj 2005. \&.
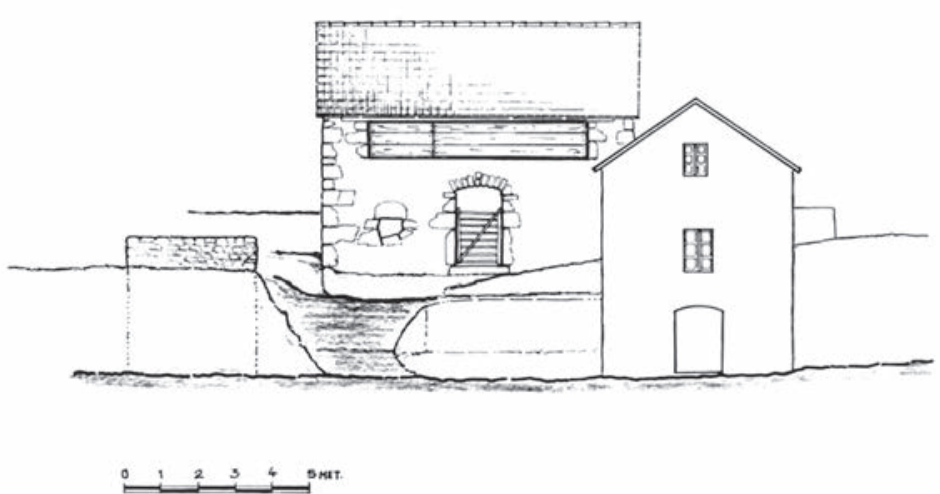

MINISTARSTVO KULTURE

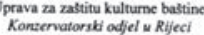
Mjesto : sjeverni Velebit, Pavidi amjena : stambeno- gospodar Snimila : Ans Persen, arb teh. Rijeka, sppanj 2005. 8

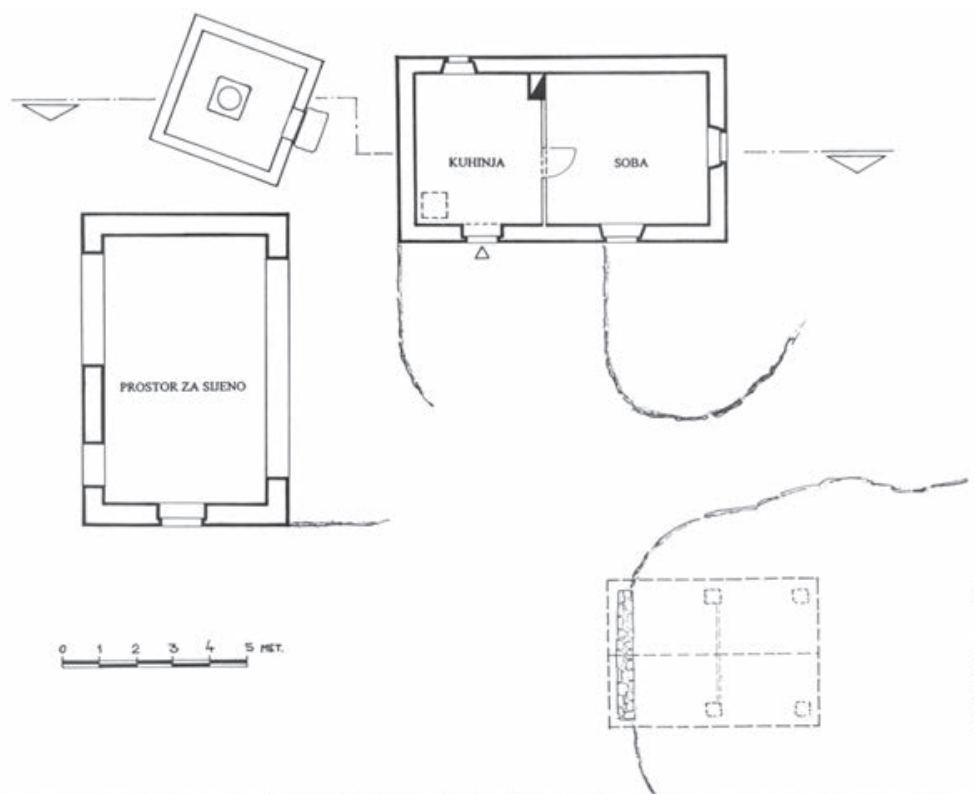

MINISTARSTVO KULTURE Uprava za zatitu kultume bastine Mjesto : sjeverai Velebit, Pavidi Narnjena : stambeno-gospodarsika Snimila: Ana Perten, Rijeka, anani 2005, \&.

Slika 4: Arbitektonski snimak, tlocrt i presjek kuce pok. Frane Pavelica (Pavici); tradicijski sklop bio je u funkciji do šezdesetih godina 20. stoljé́a. Arbiv Ministarstva kulture RH, Konzervatorski odjel u Rijeci. 


\subsection{STAMBENE I GOSPODARSKE GRAĐEVINE}

Dri gradnji korišteni su materijali koji su u prirodi bili najdostupniji: kamen i drvo. Pravila ${ }^{17,18}$ koja je 1 objavila Generalna komanda Vojne krajine u Karlovcu i proslijedila Regimenti u Otočcu radi uvođenja reda, zaštite šuma i edukacije graničara, svakako su doprinijela ekonomičnijoj eksploataciji materijala, kao i danas zanemarenoj edukaciji stanovništva o primjerenim načinima gradnje.

Neovisno radi li se o kombiniranom stambeno-gospodarskom tipu ili pak o zasebno organiziranim jedinicama, način gradnje bio je istovjetan. Zidalo se kamenom koji se vezao vapnenim mortom - meltom (vapno i pijesak - mel) ${ }^{19}$, a debljina zidova iznosila je i do $60 \mathrm{~cm} \cdot{ }^{20}$ Danas su vidljivi brojni tragovi japlenica u kojima se gasilo vapno, neophodno u tradicijskoj gradnji. I kuće i štale žbukale su se vapnenom žbukom, te jednom godišnje (ili prema mogućnostima) dodatno bijelile vapnom. Kosa konfiguracija terena vrlo je često uvjetovala da su građevine na jednoj strani prizemnice, a na drugoj katnice.

Kada je riječ o stambenoj arhitekturi, njihova je katnost varirala, kao i unutrašnja raspodjela prostora. Tek se rijetko nalaze kvalitetnije zanatske izvedbe, a tada je u pravilu riječ o imovini majstora - klesara ${ }^{21}$ koji su na taj način iskazivali vlastito umijeće. Razvoj od jednoprostorne k višeprostornim građevinama, uobičajen je, dok su tlocrti ujednačeni, pravokutni. Ukoliko se ukazala potreba za proširenjem stambenoga prostora, dograđivali su se manji lančani gabariti (rjeđe se uočavaju i tlocrti u obliku slova „T“ i „L“). Većina je stambenih građevina imala i tavan. ${ }^{22}$ Kuće su znale biti i dvokatne što je ukazivalo na

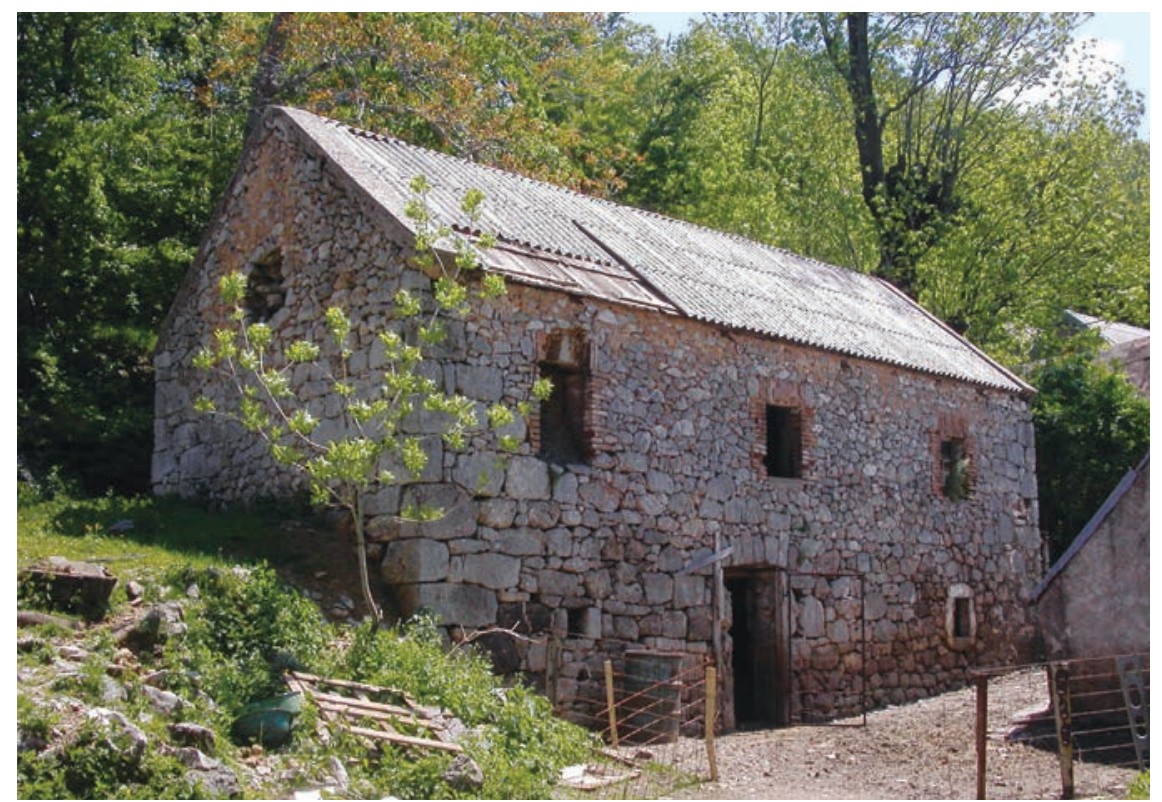

Slika 5: Cupicí, svibanj 2005; snimila Ivana Šarič Žic.

17 Radi štednje i čuvanja šuma izdaje se 1786. okružnica kojom se graničari pozivaju da zidaju kuće od kamena, a ne od drva. (Rogić 1965:46)

18 Naredbom od 2. rujna 1786. naređuje se da se seljaci pouče u cijepanju šimle jer je utvrdeno da se pri traženju cjepkih jelovih stabala uništava mnogo šume. (Rogić 1965:47)

19 U UEA, tema br. 38 (Zidovi (stijene) zgrada također nailazimo na podatak da su kameni zidovi bili vezani vapnenim mortom (malterom od vapna), ali se spominje i dodatni podatak da je kamenje bilo pritesano.

20 Rad Helene Knifić Schaps donosi podatak da se isprva gradilo troslojnim suhozidom (2 vanjska zida od krupnijeg kamena s ispunom od sitnijeg lomljenog kamena i zemlje (Knifić Schaps 2005:362), pri čemu se zaključuje da su prve nastambe Bunjevaca bile suhozidne, bez veziva.

21 Kao primjer kvalitetnije građevine u vlasnišstvu klesarske obitelji navodim kuću obitelji Tomljanović u Vrataruši, koja se ističe bogatije profiliranim ertama i povijenim kamenim potkrovnim vijencem.

22 Kuća i kućište Prpić-Grgajice: Na tavanu kuće držalo se sijeno i žitarice u bačvama, svaka vrsta zasebno. Hrana i kukuruz namalo također su bili pohranjeni na tavanu. (Černelić 2000:205). Također, na tavanima se dimilo i sušilo meso. 
bolji ekonomski i društveni status pojedine obitelji ${ }^{23}$. Arhitektura se, u prvome redu, razvijala u skladu s potrebama njezinih korisnika jer kako bi se povećavao broj članova obitelji, tako se povećavala i potreba za većim stambenim prostorom. Stoga je unutarnja dispozicija prostora u velikoj mjeri ovisila o individualnim situacijama. Osnovni (elementarni) broj prostorija činile su: kuhinja (kujinja) i soba, koje su bile grijane ${ }^{24}$. Prostor bi se naknadno vertikalno proširivao dodatkom još jedne sobe na suprotnoj strani kuhinjskog prostora. Ulaz u zatvoreni (stambeni) dio kuće bio je samo jedan.

U štalama (stajama) ${ }^{25}$, kao samostalnim građevinama (sl. 5), u prizemnom je dijelu boravila stoka (ovce, krave, konji, magarci, volovi), dok se na katu čuvalo sijeno. Otvor za ubacivanje sijena, smješten na zabatu, nazivao se badža. ${ }^{26}$

Literatura (Freudenreich 1972:277) taj termin navodi kao sinonim za vidalicu. Uz štale su bile gnojnice, $r p e,{ }^{27}$ na koje se odlagao gnoj. U prikazu teških životnih uvjeta R. Pavelić donosi i opis jutarnjih aktivnosti u kojemu navodi: Jošse u ovim krajevima ni razdanilo nije, a krave i ovce većsu pomužene, konoba okidana (gnoj izvezen na bunjište)...(Pavelić 1973:190). Također, nalazimo i štale čija gornja etaža dijelom ima drvenu oplatu, što je pridonosilo boljem ozračivanju sijena.

Krovna konstrukcija stambenih i gospodarskih građevina u pravilu je drvena, a dvostrešno krovište prekrivalo se krovnom daščicom, šimlom. Šimla se kalala $^{28}$ (cijepala) ponajprije od jelovine, rjeđe od šmrike, sve do sredine 20. stoljeća. Slagala se u dva sloja, koja su se dijelom preklapala, kako bi se izbjeglo prokišnjavanje. Trajnost te vrste krovnoga pokrova bila je, uz stalno održavanje, i do 30 godina. Međutim, već se ranih 30-ih godina 20. stoljeća kao krovni pokrovi javljaju eternit i salonit, kao gotovi proizvodi, jednostavniji za primjenu. Često se nalaze i primjeri gdje je izvorna dotrajala šimla samo prekrivena limenim pokrovom, zbog neophodne zaštite. Istiskivanjem ognjišta ${ }^{29}$ iz upotrebe i uvođenjem novijih štednjaka tzv. koza utjecalo se i na kraću trajnost šimle. Obzirom da je dim više nije prirodnim putem impregnirao, brže je i propadala. Kazivači ističu nekadašnju kvalitetu te vrste pokrova, naglašavajući da tada nije bilo kao danas, kada je drvo jutros u šumi, popodne na krovu..$^{30}$ Krovni nagibi vrlo su strmi, od $35^{\circ}$ na više, što uvjetuju teški klimatski uvjeti s dugim zimama. Na krovovima, iznad prostorije u kojoj se nalazilo ognjište, bila je vidalica ${ }^{31}$ - tradicijska inačica dimnjaka koja je služila za odvod dima obzirom da su prvotne kuhinje bile otvorenoga krovišta. Stoga ovaj tip tradicijskih kuća lokalno stanovništvo naziva dimnim kućama ili kućama na dim. Vidalica se regulirala (otvarala i zatvarala) dugačkom motkom. ${ }^{32} \mathrm{~S}$ prestankom korištenja ognjišta javlja se zatvorena drvena međukatna konstrukcija.

23 U UEA, tema br. 32. zabilježen je podatak da se "običan, stariji oblik" kuće (vremenski podatak nije preciziran, ali se odnosi na vrijeme prije šezdesetih godina 20. stoljeća) sastoji od prostora za stanovanje (kuhinja i jedna soba), tavana i podruma, dok je "danas" (šezdesetih godina 20. stoljeća) u kući jedna soba više.

24 Podatak o broju i rasporedu prostorija i lokalnom nazivu kuhinje - kujinja, nalazimo u UEA, tema br. 32, Fd $241 / 1382$.

25 Lokalni naziv staja nalazimo u UEA, tema br. 31, Fd 241/1382.

26 Termin zabilježen u Cupićima i Pavićima.

27 Zabilježeno u Cupićima.

28 Šimlu su kalali lokalni majstori. Da je taj zanat zahtijevao umješnu ruku potvrđuje i literatura: Za šindru se mogu upotrebljavati samo odabrani dijelovi debla, između redova grana koje izbijaju iz čvorova pa su zato $i$ daske razmjerno vrlo kratke 30 do $100 \mathrm{~cm}$. Kad se cijepa šindra, mora se slagati u svežnjeve istim redom kojim je iz debla izvadena, jer izmiješana ne pokriva skladno nepravilnosti u drvu. Šindra je u starim kućama pribijena drvenim klinovima a u novijim željeznim čavlima (Freudenreich 1973:119).

29 Kuća i kućište Prpić-Grgajice: Iznad ognjišta visile su komoštre na drvenoj motki hrljiki. Na komoštre bi se objesio bakreni lonac zvan kaštrola, u kome se kuhalo. Na ognjištu su bile tronoge. Pod njih se stavljala žeravica i tako se kuhalo na samome ognjištu. Kuhinja je bila sagrađena na štuk, bez tavanice. (Černelić 2000:203)

30 Ivan Prpić, Špalji.

31 Uobičajena dimenzija vidalice: 40 x $80 \mathrm{~cm}$.

32 U selu Pavići ta se šipka nazivala štandard. 
Svi otvori, prozori i vrata, u pravilu su pravokutni uokvireni rustično oblikovanim ili štokanim kamenim okvirima, supražnicama. ${ }^{33}$ Rjeđe nalazimo i lučne prizemne otvore štala, također uokvirene kamenom. Otvori su uglavnom zakriljeni drvenom stolarijom, tek ponegdje metalnom. U znatno manjoj mjeri otvore uokviruju i drvene grede ili pak okviri izvedeni u opeci, osobito kada je riječ o gospodarskim građevinama. Rijetki su primjeri datiranih građevina (sl. 6), s uklesanom godinom gradnje (npr. 1868.), najčešce na zaglavnom kamenu nadvratnika.

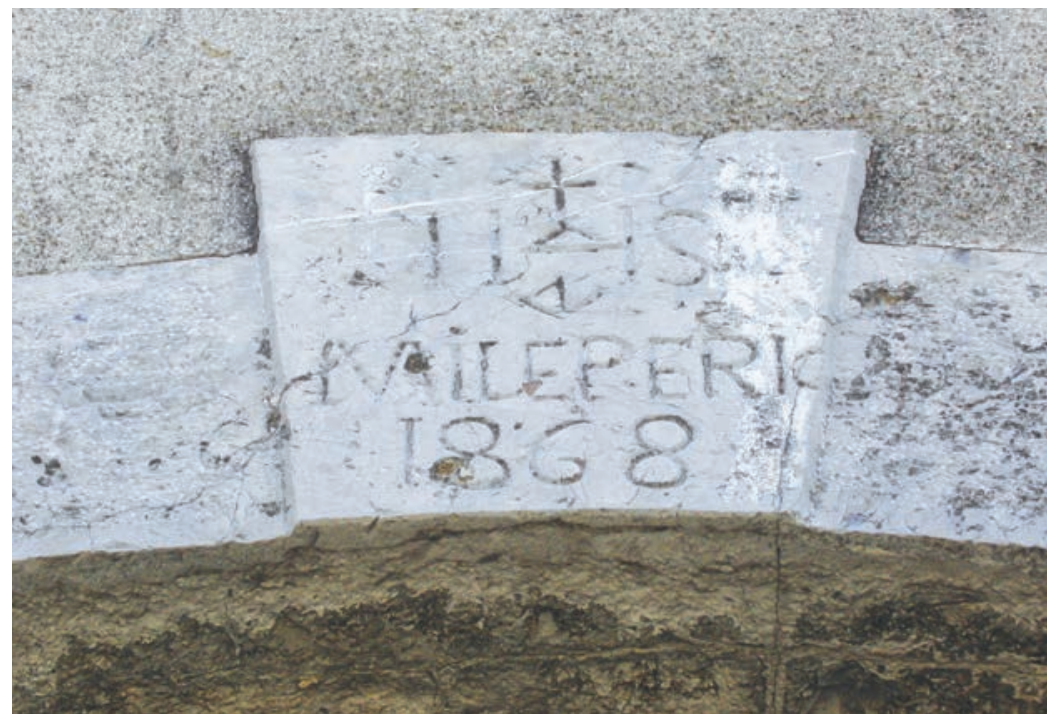

Slika 6: Francikovac, lipanj 2005; snimila Ivana Šarić Žic.

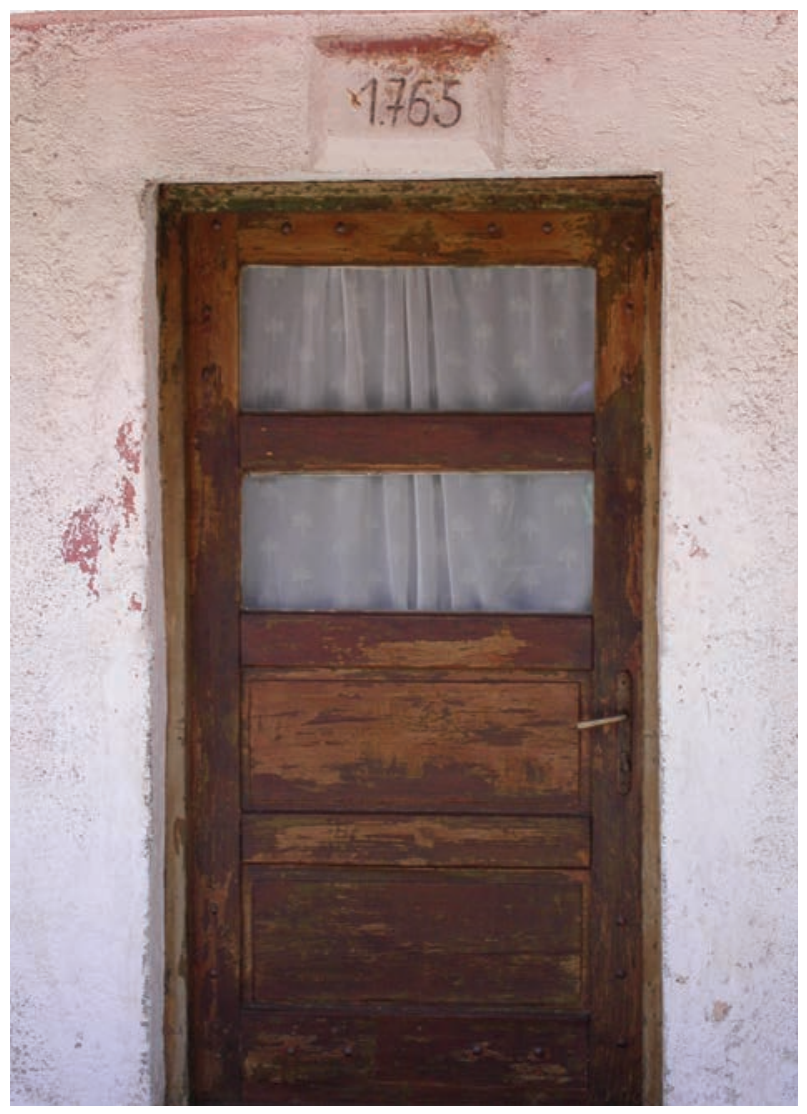

33 Termin zabilježen u Cupićima.

34 Temeljeno na podacima koje je dao Ivan Vukelić Mikula.
Zamijećene datacije kreću se u rasponu od druge polovice 19. stoljeća do dvadesetih godina 20. stoljeća, a tek je jedan uočen primjer ranije datacije (1763. god.) u zaselku Vukelići (sl. 7)

Iz cjelokupnoga graditeljskog fundusa izdvajam građevinu u vlasništvu obitelji Vukelić iz Cupića, u kojoj se živjelo do unazad dvadesetak godina. ${ }^{34}$ Premda zapuštena, ističe se upravo uobičajenom trodijelnom raspodjelom gornje stambene etaže: središnja prostorija, u kojoj je smješteno nisko ognjište, te dvije bočne prostorije - soba i spremište. Takvu unutrašnju raspodjelu srećemo i na širem geografskom području (Gorski kotar, Primorje). U sobi je i danas očuvan petnjak (sl. 8), peć od ostakljenih staklenih lončića, koju se ložilo iz središnje prostorije, kreveti slamarice kao i drugi etnografski mobilijar.

Slika 7: Datirani nadvratnik; zaselak. Vukelici; lipanj 2005; snimila Marijeta Rajkovic. 


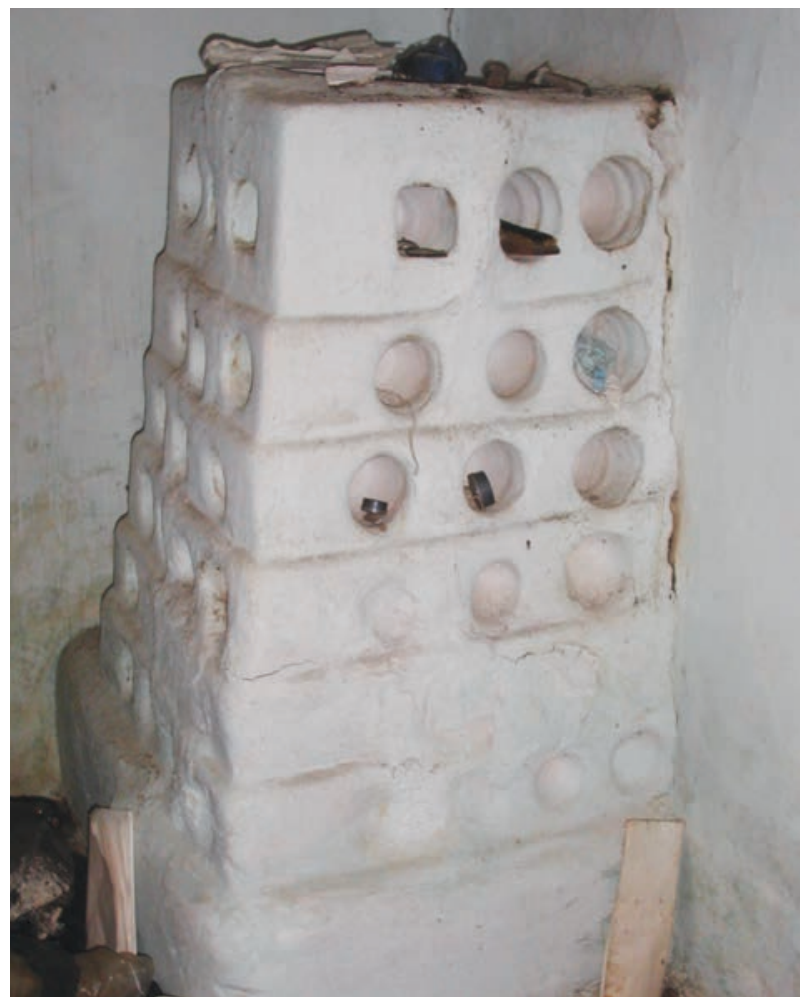

Drvenim se stubištem iz kuhinje spuštalo u štalu, smještenu u prizemlju. Navedena je komunikacija bila aktivna osobito u zimsko doba kada su veliki nanosi snijega onemogućavali pristup štali izvana. Građevina vjerojatno datira iz 18. stoljeća, obzirom na broj generacija koje su u njoj živjele (sl. 9). Godine 1912. izgrađena je susjedna kuća u koju sele tri brata s obiteljima, dok četvrti brat ostaje živjeti u opisanoj građevini.

Još se jedan oblik arhitekture izdvaja iz opisane tipologije, a to su kuće $s$ vanjskim stubištem na pročelju. U većoj ih mjeri nalazimo oko Alana (Vukelići, Zamalić), što je zasigurno utjecaj tradicijske arhitekture vinodolskoga područja gdje je taj tip arhitekture uobičajen. Tek sporadično, kao izolirane primjere, takve građevine nalazimo i drugdje na području Krivoga Puta (Francikovac, Špalji).

Slika 8: Cupićí, listopad 2006; snimila Ivana Šarić Žic

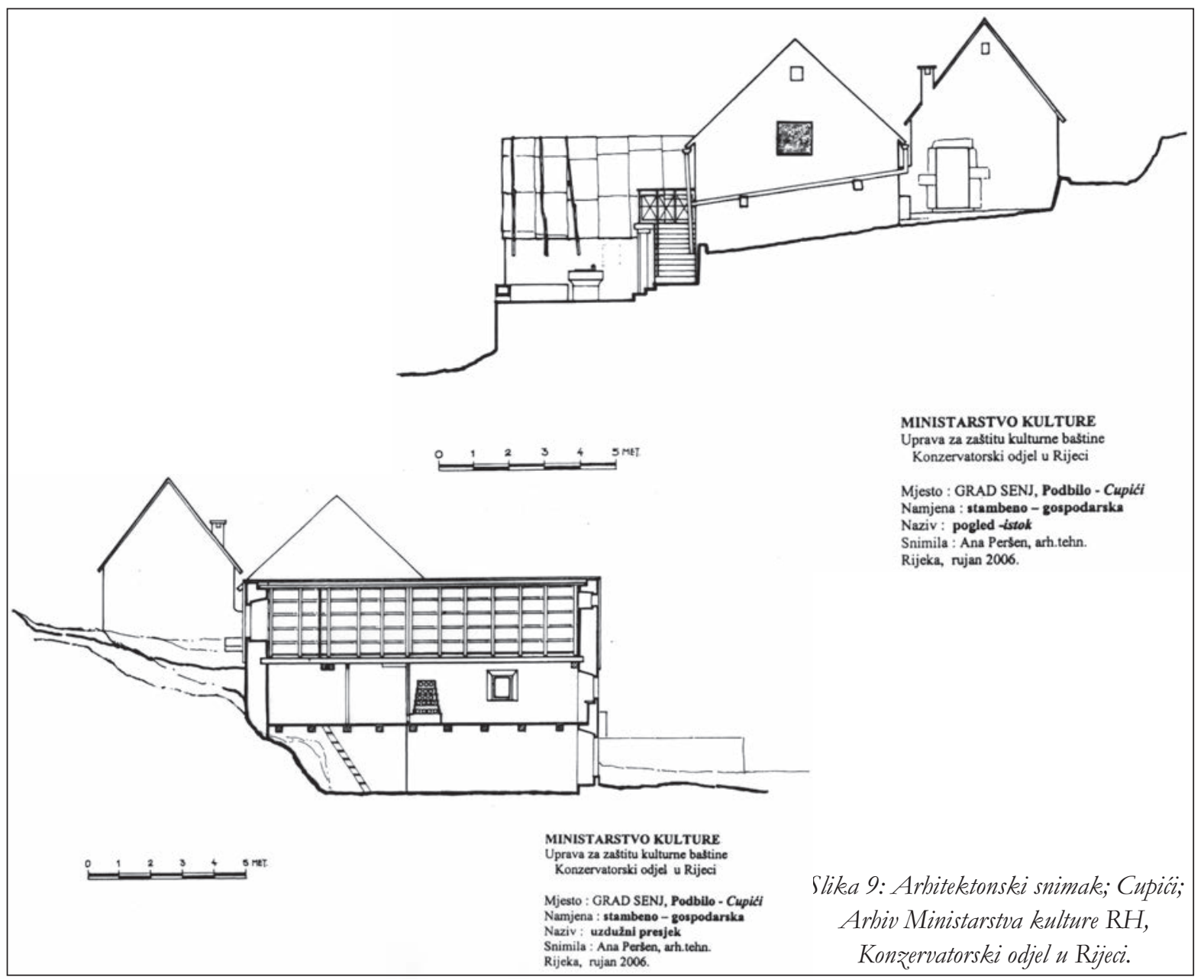




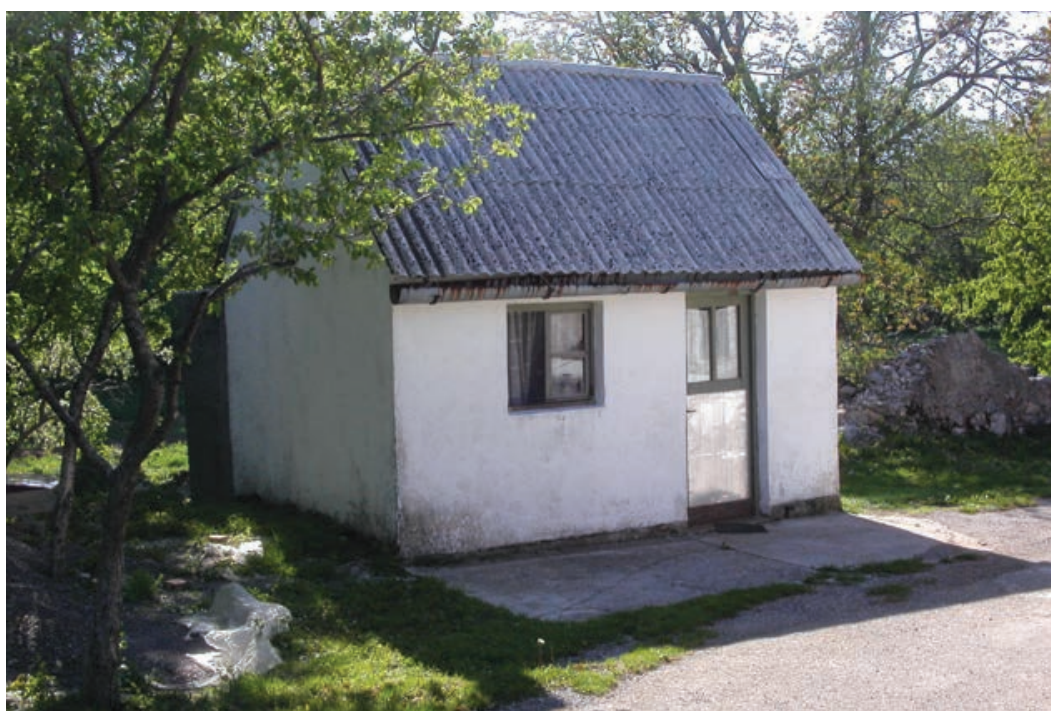

Slika 10: Rupa, svibanj 2005; snimila Ivana Šarič Žic.

\subsection{TRADICIJSKA OKUĆNICA ${ }^{35}$}

7 načajne građevine u tradicijskom graditeljstvu tog prostora su i bajte (sl. 10), ljetne kuhinje smještene u neposrednoj blizini kuće. Bajte ${ }^{36}$ su jednoprostorne prizemne građevine manjih gabarita, uglavnom građene od kamena, s utabanom ilovačom, izvorno prekrivene šimlom. U njima je također bilo ognjište na kojem se kuhalo za blago, ali i za ljude. Danas se primjeri takve tradicijske gradnje vrlo često nalaze, mnogi od njih su i novijeg datuma, međutim interijeri su znatno osuvremenjeni, prilagođeni potrebama i navikama današnjega čovjeka. Iako opis termina „bajta“ koji donosi A. Freudenreich, ${ }^{37}$ nema veze $s$ karakteristikama bajti koje nalazimo na prostoru Krivoga Puta, istovjetna je skromnost opisane arhitekture.

Od ostalih gospodarskih građevina unutar tradicijske okućnice nalazimo i kolnice, spremišta za kola i ratarska pomagala. Prema kazivanjima bile su jednostrešnog krovišta, prekrivene također šimlom, a u današnje vrijeme im ne nalazimo traga. ${ }^{38}$

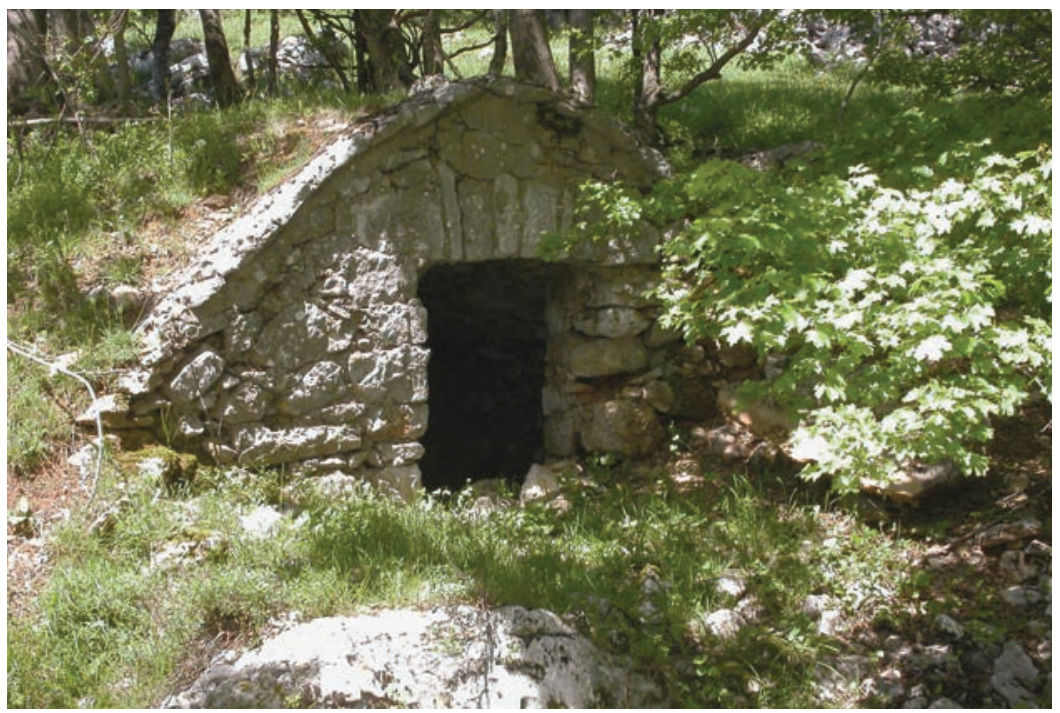

Slika 11: Cupicí, svibanj 2005, snimila Ivana Šarič Žic.

35 Kuća i kućište Tomljanović-Puljiz. Naziv za dvorište je prikuća. (Černelić 2000:206)

36 U Pavićima je zabilježen i naziv kuvarija.

37 Bajta - koliba, improvizirana šatorasta dvostrešna nastamba od kolja, šiblja, šaša, slame, kore drveta, gradevnih otpadaka i drugoga gradiva, u drugom svjetskom ratu. (Freudenreich 1972:277).

38 Kako tvrdi Ivan Prpić iz Špalja na vratima je bila rupa za rudo koje i nije moralo stati u kolnicu. 
Svako domaćinstvo imalo je trap (sl. 11), ukopano spremište dubine oko 1,5 m, smješteno u podrumu građevine ili u okućnici kao samostalan objekt minimalnih dimenzija (nadzemni dio oko 1,5 x 2,0 m). U njemu se čuvao krumpir i zeljasto povrće ${ }^{39}$. Većina ih je imala šimlu za pokrov, naknadno zamijenjenu limom.

Neizostavan element u tradicijskoj okućnici su vodospreme, šterne. (sl. 12) O njihovu značaju govori i kazivanje kako je šterna znala livadu pokosit. ${ }^{40}$ To jasno upućuje da je u zamjenu za vodu lokalno stanovništvo obavljalo različite poslove.

Međutim, šterne ${ }^{41}$ se razlikuju kvalitetom izvedbe. Starija su kruništa izvedena kamenom, kružnog su ili kvadratičnog presjeka. Često su na njima uklesane odnosno ušpicane godine izvedbe i nerijetko su pokazatelji umješnosti lokalnih graditelja. Uglavnom datiraju iz druge polovice 19. stoljeća, a uz dataciju nerijetko je istaknut i Kristov monogram, kao i inicijali majstora ili vlasnika.

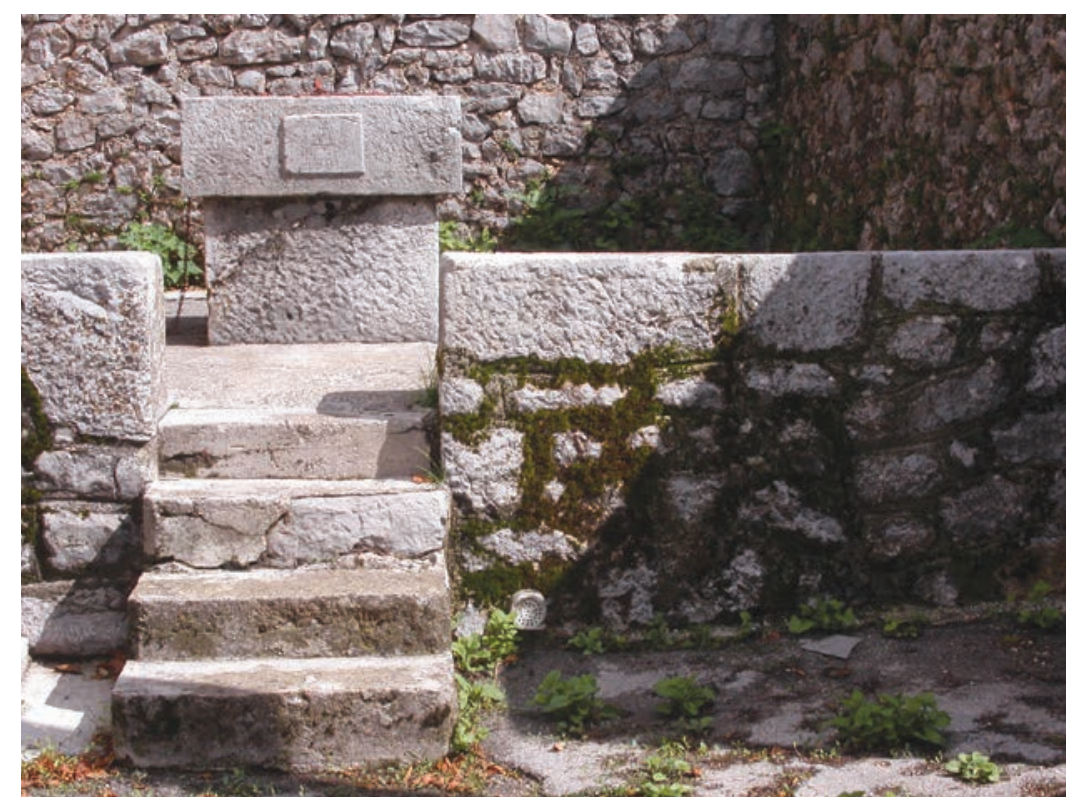

Slika 12: Dudici, Brunicí, rujan 2005; snimila Ivana Šarić Žic.

Šterne novijega datuma izrađene su u betonu i njihov je broj veći u odnosu na kamene, s obzirom da je njihova izgradnja bila znatno jeftinija. Budući da ovaj predio ni danas nema provedenu vodovodnu infrastrukturu preostalom su stanovništvu one i nadalje jedini izvor vode. ${ }^{42}$

Uz vodospreme, ponegdje nalazimo i saliže (sl. 13) (Francikovac, Gornji Veljun), veće naplavne površine blagog nagiba niz koje se kišnica slijeva u vodospremu.

Tradicijske kuće nisu imale sanitarne čvorove, a obilazeći prostor, danas još nalazimo zahode iz kasnijega vremena, kao samostojeće objekte unutar okućnice.

Svaka je okućnica imala i manji vrt, a zgrade na okućnici bile su raspoređene nepravilno ${ }^{43}$.

39 U UEA, tema br. 32 nailazimo na podatak da se u podrumu čuvalo: krumpir, zelje i alat.

40 Podatak zabilježen u Pavićima u lipnju 2005. godine. Nažalost, ime kazivača nije zabilježeno.

41 Kuća i kućište Prpić-Grgajice Pred kućom je bila šterna, iz koje se kalala (vadila) voda kalačom, limenim vedrom na lancu, koje se rukom izvlačilo. (Černelić 2000:205)

42 Detaljnije o opskrbi vodom u radu Danijele Birt (prilog u Monografiji).

43 Podatak o nepravilnom razmještaju dijelova okućnice nalazimo u UEA, tema br. 31, Fd 241/1382. 


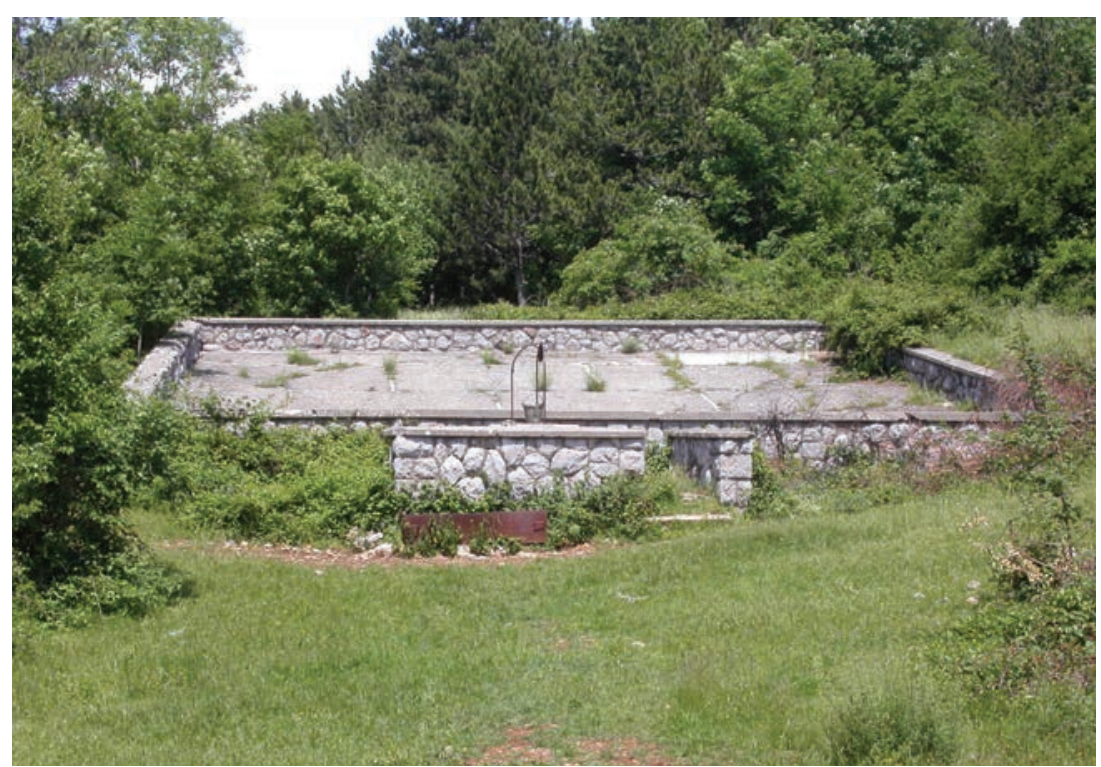

Slika 13: Francikovac; lipanj 2005; snimila Marijeta Rajković.

\subsection{GRAĐEVINE JAVNE NAMJENE}

Dosebno mjesto u arhitektonskim oblicima ovoga prostora svakako pripada i arhitekturi školskih građevina. Mirko Raguž bavio se problematikom školstva, no bez interesa za samu arhitekturu, koja ipak zaslužuje biti predmetom posebnoga rada. Kao osobito kvalitetno arhitektonsko zdanje na ovom se području ističe škola u Vukelićima. Premda danas ruševna, predstavlja primjer tzv. definirane arhitekture, vjerojatno rađene prema naručenom projektu.

Obzirom na geografski položaj područja Krivoga Puta, kojim su prolazili trgovci, kupci i trajbari ${ }^{44} s$ ličkih sajmišta prema moru, nalazimo i kvalitetnije primjerke arhitekture većih dimenzija koji su služili kao gostionice i prenoćišta (svratišta) za trgovce i stoku. Osobito se ističe ono u Francikovcu, koje je pripadalo obitelji P(e)rpić, vjerojatno podignuto 1865 . godine, što potvrđuje godina uklesana u nadvratnik zajedno s Kristovim monogramom. Prizemlje (podrum) te građevine presvođeno je voltima, a cijela je okućnica

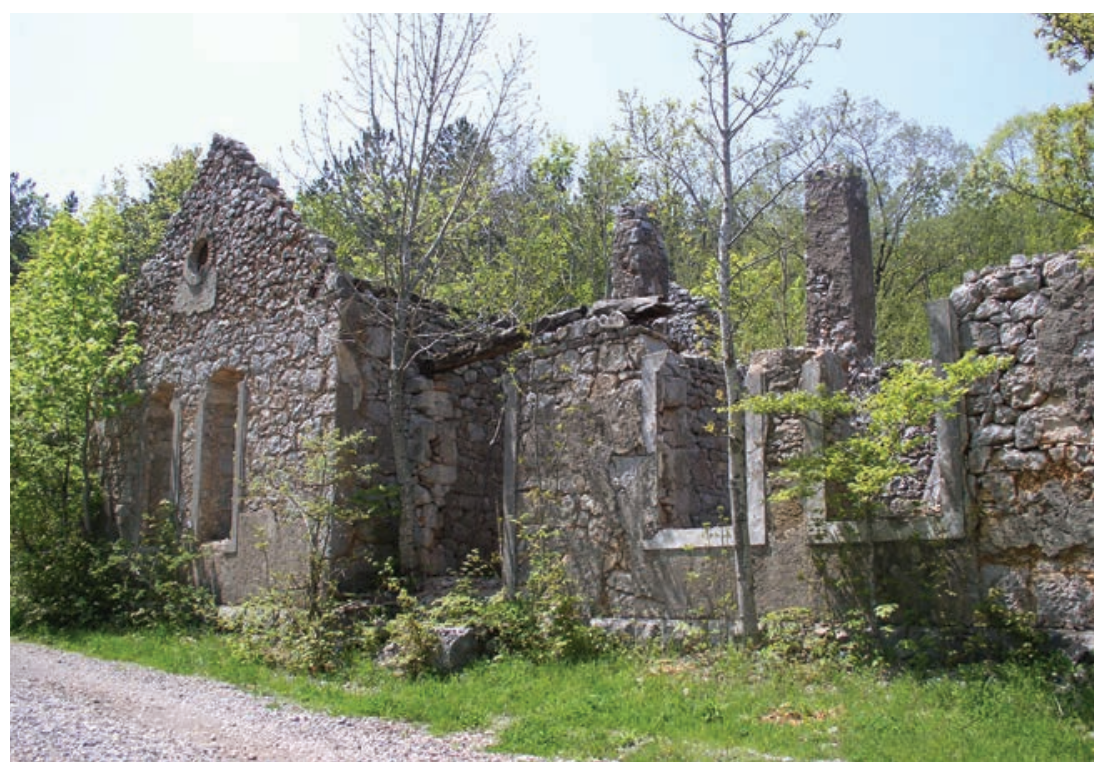

Slika 14: Ruševine škole u Vukelicima, Alan; svibanj 2005; snimila Marijeta Rajković

44 Plaćeni ljudi koji bi iz sajmišnih mjesta izgonili stoku do odredenog mjesta. Na putu su imali svoje konte [stalna prenoćišta, op.a.] gdje bi noćivali. (Rubić 2004:307) 
ograđena visokim zidom. Prema poznatim podacima (Rubić 2004:287-324), gostionica i prenoćišta bio je veći broj, no ovo se ističe dimenzijama i oblikovanjem. U istoj je okućnici očuvan i tor, također opasan visokim zidom, s masivnim lučnim ulazom, bez datacije (sl. 14). Nije isključeno da je ovo jedina svođena građevina (prema dosadašnjim saznanjima), što je svakako upućivalo i na imućnost obitelji.

Može se pretpostaviti da su graditelji bili profesionalni klesari iz vinodolskoga područja. Razlog dobre očuvanosti ovoga kompleksa sigurno je stalna nastanjenost i živa gospodarska djelatnost, što predstavlja i kvalitetno ishodište za razvoj nekog tipa ruralnoga turizma.

Arhitektonski je snimljen i sklop u Klarićevcu, također ograđen visokim zidom. Sklop nije detaljno istraživan, tek su poznati podaci da je tu neko vrijeme djelovala pošta, te da je u tom prostoru bila i tzv. Cotina birtija (sl. 15) ${ }^{45}$
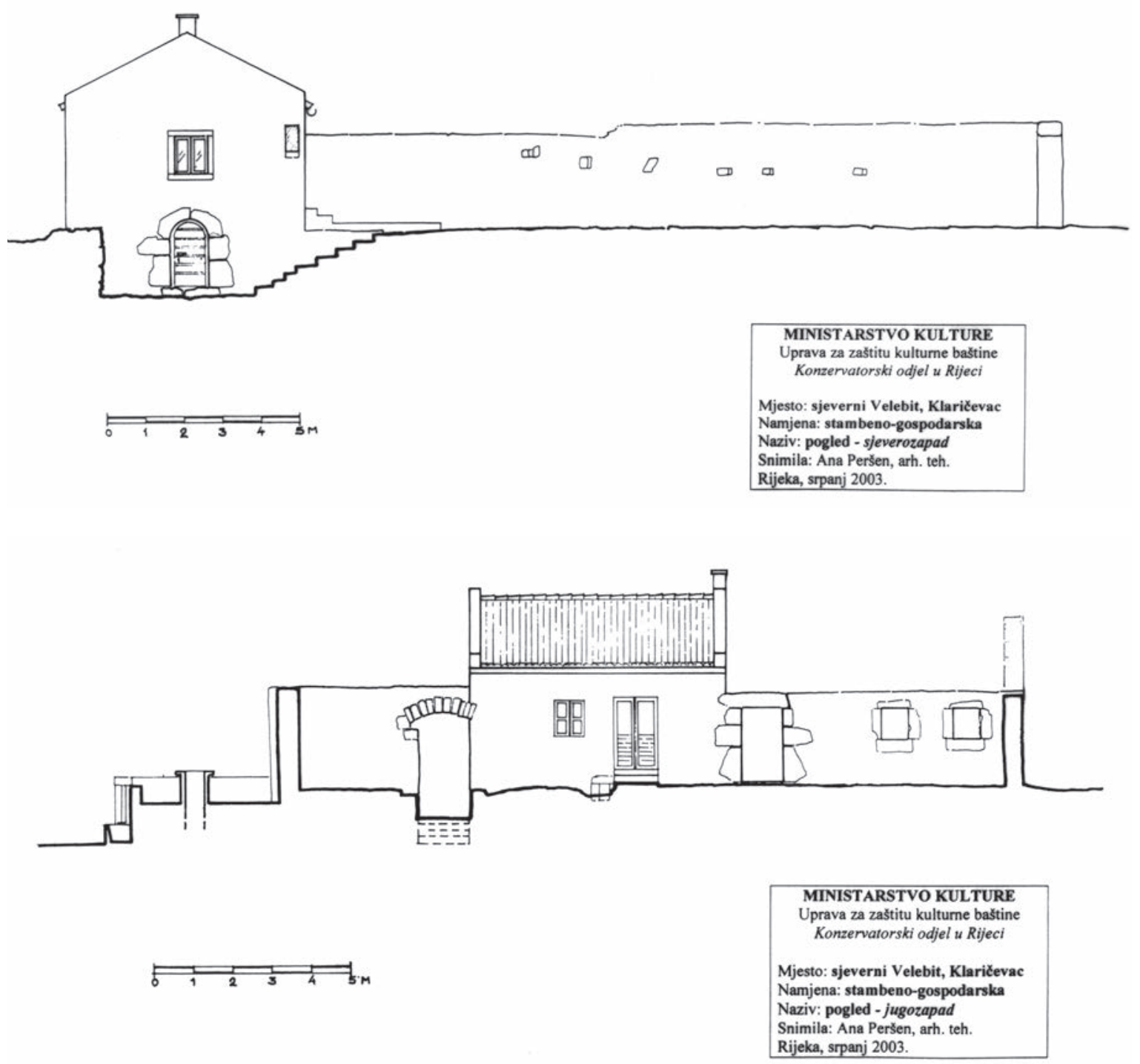

Slika 15: Arbitektonski snimci; Klaricevac/ pogled SZ i JZ; Arbiv Ministarstva kulture RH, Konzervatorski odjel u Rijeci.

$\overline{45}$ Detaljnije o gostionicama u prilogu T. Rubić u ovoj monografiji. 


\section{GRADITELJSTVO OČIMA DOMICILNOGA STANOVNIŠTVA}

U pokušaju definiranja stajališta i predodžbi samih pripadnika zajednice o odlikama naslijeđene arhitekture, stječe se dojam da je upravo tradicijsko graditeljstvo ono što stanovništvo najmanje percipira kao vrijedno kulturno naslijeđe. Možda je to zato što je ona odveć životna, pa nikad nije bilo vremena obazreti se na nju niti je vrednovati kao spomenička stvaralačka djela, kao umjetničku baštinu prošlosti. I danas, gdje još postoji ona jednako i uglavnom služi svakodnevnu životu. (Premerl 1997:43) Prilikom terenskoga istraživanja, zanimljivo je istaknuti, a čemu sam osobno svjedočila, u razgovoru o tradicijskom graditeljstvu stanovništvo nerijetko pojašnjava kako ne nalazi osobitih zanimljivosti u gradnji u kojoj žive i koja ih okružuje. Uglavnom je predlagalo: pitajte šta drugo.

Kuća od starine, kako je u razgovoru naziva većina, predstavlja segment kulturne baštine na koji lokalno stanovništvo gleda vrlo racionalno, neopterećeno njezinom jednostavnošću. Kako naglašava Marko Pavelić Mijatin iz Žuljevića: Tada se nije moglo probrat, ${ }^{46}$ sugerirajući time kako skromni životni uvjeti nisu ni pružali mogućnost kvalitetnijega stanovanja. Međutim, isto tako naglašava da su te kuće bile dobre, ali vlažne. Jednostavnost ruralne arhitekture potvrđuje i Đura Biondić iz obližnjeg Liskovca riječima: Ko je tada bija da je ima lipu kuću? Pa više smo bili vani nego u kući! (Škrbić Alempijević 2003:435).

Radi sagledavanja i drugih aspekata tradicijskoga graditeljstva, svakako bi bilo potrebno u daljnjem istraživanju pozabaviti se i temama poput utjecaja tradicijskoga graditeljstva pri gradnji novih kuća na području grada Senja te stavovima Senjana o arhitekturi primorsko-bunjevačke zajednice.

\section{ZAKLJUČAK ${ }^{47}$}

$\int \operatorname{lj}$ edan od suvremenih koncepata očuvanja graditeljske baštine jest njezina revitalizacija, odnosno "oživljavanje” kvalitetnim i primjerenim prenamjenama, kako bi se zadovoljile potrebe suvremenoga života, uz uvjet očuvanja karaktera i integriteta same arhitekture.

Zbog gubitka funkcije koju su nekada imale i nenalaženja nove, te su građevine izložene sve rapidnijem propadanju. Stoga im je, kako bi se očuvala njihova ambijentalna i arhitektonska vrijednost, potrebno dati nove sadržaje, u okvirima agro-turizma i eko-turizma. Međutim, pri tim prenamjenama valja biti vrlo pažljiv kako one ne bi rezultirale gubitkom vrijednosti same arhitekture. Prema tome, planove revitalizacije poželjno je temeljiti na konzervatorskim elaboratima koji će poticati kvalitetnu obnovu postojećih i prezentaciju izvornih tradicionalnih građevina kako bi se izbjegla nekontrolirana izgradnja replika, a ujedno umanjio rizik narušavanja očuvanoga pejzaža. Rekonstrukcija pritom ne isključuje, u skladu s novom najčešće turističkom namjenom objekata, izvedbu dogradnji (ukoliko postojeći gabariti ne zadovoljavaju potreban kapacitet). Te bi se dogradnje morale razvijati u tradicionalne „T“ $\mathrm{i}$ „L“-tlocrte te uključivati neophodno osuvremenjivanje interijera kako bi nova funkcija bila kvalitetno zadovoljena. Pritom je obavezno korištenje tradicijskih materijala poput šimle i drvene stolarije (korištenje aluminijske bravarije, trend koji nekontrolirano zahvaća naseljene cjeline, nije dozvoljeno). Izmjenu plašta pročelja u pravilu treba svesti na minimum jer prečesto rezultira pretjeranim proširivanjem otvora, kao i neuklopivim dogradnjama i nadogradnjama, te gotovo grotesknim balkonima i terasama. I pri novoj gradnji potrebno je poštivati navedene smjernice, dok se tlocrtni i visinski gabariti također moraju oslanjati na naslijeđenu tipologiju.

No, bez povoljnih poticajnih mjera nerealno je očekivati “oživljavanje” krivoputskoga prostora. Malobrojno lokalno stanovništvo prisiljeno je boriti se za osnovnu egzistenciju, a nažalost, i nedovoljno je svjesno vrijednosti tradicijskih oblika arhitekture. U našim okvirima, ideje o kvalitetnom ruralnom, eko-turizmu ili agro-turizmu, još su u začecima (za razliku od europskih trendova), bez jasno

\footnotetext{
46 Zabilježeno u lipnju 2006. godine.

47 Ovo je poglavlje gotovo u cijelosti preuzeto iz rada iste autorice (Šarić Žic 2004:41-42).
} 
profiliranih ciljeva i načina njihova ostvarenja. Stoga, uz izravan poticaj na višim razinama (državnim, regionalnim ili lokalnim), važan je preduvjet i stalna te sustavna edukacija lokalnog stanovništva o vrijednostima takve arhitekture te senzibiliziranje potencijalnih projektanata, uz financijsku podršku.

Revitalizacija tih prostora uključuje i infrastrukturnu rekonstrukciju, što bi omogućilo stvaranje prihvatljivoga okvira za kvalitetnu turističku valorizaciju. To uključuje vodoopskrbnu mrežu kao i bolju prometnu povezanost.

Ono što tom prostoru, uz očuvanu tradicionalnu arhitekturu, daje iznimnu vrijednost, kulturni je krajolik s brojnim suhozidima, na čijem je očuvanju također potrebno ustrajati.

\section{LITERATURA}

BELAJ, Vitomir (2004): Tradicijsko planinsko stočarstvo na Velebitu i bunjevačka etnogeneza. Studia ethnologica Croatica, 16:5-31, Zagreb.

ČERNELIĆ, Milana (2000): Dvije zadružne obitelji na području Krivog Puta. Senjskizbornik, 27:199-216, Senj.

ČERNELIĆ, Milana (2005): Pristupi istraživanju bunjevačkih identiteta. Studia ethnologica Croatica, 17:25-49, Zagreb.

FREUDENREICH, Aleksandar (1972): Kako narod gradi na području Hrvatske. Republički Zavod za zaštitu spomenika kulture, Zagreb.

KNIFIĆ SCHAPS, Helena (2005): Turinski Krč, graditeljsko nasljeđe, povijest i sadašnjost zaselka u sjevernom Velebitu po pripovijedanju njegovih zadnjih stanovnika. Senjski zbornik, 32:349-376, Senj.

MURAJ, Aleksandra (1998): Stanovanje. U: ur. Jasna Čapo Žmegač [et al.], Etnografija (svagdan i blagdan hrvatskoga puka), Matica hrvatska, Zagreb, 24-55.

PAVELIĆ, Rikard (1973): Bunjevci. Osobna naklada, Zagreb.

PREMERL, Tomislav (1997): Živa baština ili muzej. U: ur. Ksenija Marković, Obnova i očuvanje hrvatske pučke graditeljske baštine, Ministarstvo kulture RH, Zagreb, 43-45.

RAJKOVIĆ, Marijeta (2005): Sezonske migracije na području Krivog Puta: tradicija u recentnoj povijesnoj perspektivi. Senjski zbornik, 32:273-316, Senj.

ROGIĆ, Pavle (1965): Naseljenost velebitske primorske padine kroz hitoriju. Senjski zbornik, 1: 35-68, Senj.

RUBIĆ, Tihana (2004): Trgovina i sajmovi - rezultati istraživanja na području Općine Krivi Put. Senjski zbornik, 31:287-324, Senj.

ŠARIĆ ŽIC, Ivana (2004): Tradicijsko graditeljstvo senjskog zaleđa: osvrt konzervatora. Studia ethnologica Croatica, 16:33-45, Zagreb.

ŠKRBIĆ ALEMPIJEVIĆ, Nevena (2003): Prilozi poznavanju primorsko-bunjevačkog identiteta. Senjski zbornik, 30:425-444, Senj.

ŽIVKOVIĆ, Zdravko (1993): Hrvatsko narodno graditeljstvo. Ministarstvo kulture i prosvjete, Zagreb.

\section{IZVOR}

Upitnice Etnološkog atlasa (UEA), Teme br.: 31. Kućište (okućnica), 32.. Kuća za stanovanje ljudi, 33. Prostorije i njihova namjena u kući, 35. Skladišta za žitarice, 36. Spremišta za vino, pecare, sušnice, 38. Zidovi (stijene) zgrada, 39. Krov, 40. Otvori na zgradama i visina prostorija, 41. Podovi, stropovi i unutrašnja obrada zidova; Fd 241/1382 (Krivi Put), Arhiv Odsjeka za etnologiju i kulturnu antropologiju, Filozofski fakultet u Zagrebu. 